\title{
Penerapan Model Course Review Horay dengan Media Grafis dalam Peningkatan Pembelajaran IPS tentang Jenis Pekerjaan pada Siswa Kelas III SD Negeri 1 Wirun Tahun Ajaran 2018/2019
}

\author{
1,2,3 Universitas Sebelas Maret \\ septydewi497@gmail.com
}

Septy Dewi Purwanti ${ }^{1}$, Ngatman ${ }^{2}$, Ratna Hidayah ${ }^{3}$

\section{Article History}

accepted 01/10/2019

\begin{abstract}
This study aimed to improve social science learning about the types of jobs through the application of the Course Review Horay model with graphic media. Classroom action research (CAR) was carried out for three cycles. Each cycle consists of planning, implementation, observation, and reflection. The subjects of this study were Grade III students of SD Negeri 1 Wirun, totalling 34 students. The results of the study showed that the application of the Course Review Horay model with graphic media could improve social studies learning about the type of jobs in third grade students of SD Negeri 1 Wirun in Academic Year 2018/2019. This is evidenced by the percentage of completeness of students' learning outcomes in the first cycle = $64.71 \%$, cycle $I I=79.41 \%$, and cycle $I I I=89.71 \%$.
\end{abstract}

Keywords: Course Review Horay, graphic media, social studies, types of jobs

\section{Abstrak:}

Tujuan penelitian ini yaitu meningkatkan pembelajaran IPS tentang jenis pekerjaan melalui penerapan model Course Review Horay dengan media grafis. Penelitian tindakan kelas (PTK) ini dilakukan selama tiga siklus. Setiap siklus terdiri dari perencanaan, pelaksanaan, observasi, dan refleksi. Subjek penelitian ini adalah siswa kelas III SD Negeri 1 Wirun yang berjumlah 34 siswa. Hasil penelitian menunjukkan bahwa penerapan model Course Review Horay dengan media grafis dapat meningkatkan pembelajaran IPS tentang jenis pekerjaan pada siswa kelas III SD Negeri 1 Wirun tahun ajaran 2018/2019 yang dibuktikan dengan persentase ketuntasan hasil belajar siswa pada siklus $\mathrm{I}=64,71 \%$, siklus $\mathrm{II}=79,41 \%$, dan siklus $\mathrm{III}=89,71 \%$

Kata kunci: Course Review Horay, media grafis, IPS, jenis pekerjaan 


\section{PENDAHULUAN}

Pendidikan merupakan upaya yang tepat untuk menyiapkan dan membangun sumber daya manusia (SDM) berkualitas dan bermutu tinggi, sehingga kualitas kehidupan masyarakat Indonesia dapat meningkat dan mampu bersaing dengan negara asing di era global.

Pada dunia pendidikan, siswa harus menguasai kompetensi $4 \mathrm{C}$ yaitu creativitas and innovation, critical thinking and problem solving, communication, dan collaboration (Kemendikbud,2017:6). Kompetensi 4C tersebut dapat diajarkan melalui pembelajaran di sekolah. Salah satunya melalui pembelajaran IPS.

IPS merupakan ilmu pengetahuan yang mengkaji berbagai disiplin ilmu sosial dan humaniora serta kegiatan manusia yang dikemas secara ilmiah dengan tujuan untuk memberi wawasan dan pemahaman yang mendalam kepada peserta didik khususnya di tingkat dasar dan menengah (Susanto, 2013:137).

Tujuan pendidikan IPS menurut Tim Guru SD N 1 Wirun (2018:24) diantaranya yaitu: (a) mengenal konsep-konsep yang berkaitan dengan kehidupan masyarakat di lingkungan, dan (b) memiliki kemampuan dasar untuk berpikir logis dan kritis, rasa ingin tahu, inquiry, memecahkan masalah, dan keterampilan dalam kehidupan sosial.

Namun, dalam proses pembelajaran IPS di SD sering muncul permasalahan mengenai pelaksanaan pembelajaran yang kurang optimal sehingga berakibat pada pencapaian kompetensi-kompetensi yang belum maksimal. Hal ini terjadi karena dipengaruhi oleh pembelajaran yang kurang inovatif.

Permasalahan pembelajaran IPS tersebut juga dialami di kelas III SD Negeri 1 Wirun. Berdasarkan hasil observasi dan wawancara yang dilakukan oleh peneliti terhadap guru kelas III SD Negeri 1 Wirun pada hari Selasa, 18 September 2018 diperoleh keterangan bahwa pada pembelajaran IPS di sekolah tersebut meliputi: (1) pembelajaran dengan model konvensional, (2) belum menerapkan model pembelajaran yang inovatif, dan (3) belum menggunakan media pembelajaran.

Permasalahan lainnya yaitu berkaitan dengan hasil belajar IPS siswa kelas III. Hasil belajar UTS 1 mata pelajaran IPS tahun ajaran 2018/2019 menunjukkan bahwa dari 34 siswa, hanya ada 20 siswa yang tuntas mencapai $\mathrm{KKM}=70$. Apabila dipersentasekan maka hanya ada $58,82 \%$ siswa yang sudah mencapai KKM dan $41,17 \%$ siswa yang belum mencapai KKM.

Berdasarkan kenyataan tersebut, peneliti menawarkan solusi pembelajaran yang melibatkan keaktifan siswa, memberikan pengalaman langsung, dan meningkatkan motivasi belajar siswa dalam memahami materi IPS melalui penerapan model Course Review Horay dengan media grafis.

Course Review Horay merupakan model pembelajaran kooperatif yaitu kegiatan belajar mengajar dengan cara pengelompokkan kecil dan untuk menguji terhadap pemahaman konsep siswa menggunakan kotak yang diisi dengan soal dan diberi nomor untuk menuliskan jawabannya. Siswa yang paling terdahulu mendapatkan tanda benar maka langsung teriak horay atau yel-yel lainnya (Shoimin ,2014:54-55).

Pendapat lain diungkapkan oleh Huda (2013:229-230) bahwa Course Review Horay merupakan model pembelajaran yang dapat menciptakan suasana kelas menjadi meriah dan menyenangkan karena setiap siswa yang dapat menjawab dengan benar diwajibkan berteriak "horee!!" atau yel-yel lainnya yang dipakai

Media grafis adalah media visual yang berfungsi untuk menarik perhatian, memperjelas sajian ide, mengilustrasikan atau menghiasi fakta yang mungkin akan cepat dilupakan atau diabaikan jika tidak digrafiskan (Sadiman, dkk, 2014:28). Pendapat lain disampaikan oleh Sardiman (Sanaky, 2015:81) yaitu media grafis termasuk media visual yang penyaluran pesannya mengutamakan indera penglihatan dan pesan yang disampaikan dituangkan ke dalam bentuk simbol-simbol visual. 
Langkah-langkah penerapan model pembelajaran Course Review Horay dengan media grafis meliputi: (1) penyampaian kompetensi, (2) penyajian materi dengan media grafis, (3) tanya jawab, (4) pembagian kelompok, (5) pembuatan kotak di lembar diskusi, (6) pembacaan soal, (7) diskusi kelompok, (8) pemberian tanda check list $(\checkmark)$, (9) penghitungan skor, (10) pemberian reward. Langkah-langkah tersebut merupakan pengembangan dari langkah Course Review Horay menurut Huda (2013:230) dan Shoimin (2014:55).

Rumusan masalah dalam penelitian ini yaitu: (1) Bagaimana penerapan model Course Review Horay dengan media grafis dalam peningkatan pembelajaran IPS tentang jenis pekerjaan pada siswa kelas III SD Negeri 1 Wirun tahun ajaran 2018/2019?, (2) Apakah penerapan model Course Review Horay dengan media grafis dapat meningkatkan pembelajaran IPS tentang jenis pekerjaan pada siswa kelas III SD Negeri 1 Wirun tahun ajaran 2018/2019?, dan (3) Apa kendala dan solusi pada penerapan model Course Review Horay dengan media grafis dalam peningkatan pembelajaran IPS tentang jenis pekerjaan pada siswa kelas III SD Negeri 1 Wirun tahun ajaran 2018/2019?

Tujuan penelitian ini yaitu: (1) mendeskripsikan penerapan model Course Review Horay dengan media grafis dalam peningkatan pembelajaran IPS tentang jenis pekerjaan, (2) meningkatkan pembelajaran IPS tentang jenis pekerjaan melalui penerapan model Course Review Horay dengan media grafis, dan (3) mendeskripsikan kendala dan solusi dalam penerapan model Course Review Horay dengan media grafis dalam peningkatan pembelajaran IPS tentang jenis pekerjaan pada siswa kelas III SD N 1 Wirun tahun ajaran 2018/2019.

\section{METODE}

Penelitian ini merupakan penelitian tindakan kelas (PTK) kolaboratif. Penelitian dilaksanakan di SD Negeri 1 Wirun dengan subjek penelitian yaitu siswa kelas III SD Negeri 1 Wirun tahun ajaran 2018/2019 yang berjumlah 34 siswa. penelitian ini dilaksanakan mulai bulan September 2018 - April 2019.

Data yang digunakan berupa data kualitatif dan kuantitatif. Teknik pengumpulan data menggunakan observasi, wawancara, dan tes. Validitas data menggunakan triangulasi teknik dan triangulasi sumber data. Analisis data dilakukan melalui reduksi data, penyajian data, dan kesimpulan.

Indikator kinerja penelitian baik dari segi proses oleh guru dan siswa maupun hasil pelaksanaan pembelajaran melalui penerapan model Course Review Horay dengan media grafis sebesar $85 \%$. KKM hasil belajar yang ditargetkan pada penelitian ini yaitu 75 .

Penelitian dilaksanakan selama 3 siklus. Setiap siklus terdiri dari 2 pertemuan dengan tahapan kegiatan yaitu (1) perencanaan, (2) pelaksanaan, (3) pengamatan, dan (4) refleksi.

\section{HASIL DAN PEMBAHASAN}

Langkah-langkah penerapan model pembelajaran Course Review Horay dengan media grafis meliputi: (1) penyampaian kompetensi, (2) penyajian materi dengan media grafis, (3) tanya jawab, (4) pembagian kelompok, (5) pembuatan kotak di lembar diskusi, (6) pembacaan soal, (7) diskusi kelompok, (8) pemberian tanda check list $(\checkmark)$, (9) penghitungan skor, (10) pemberian reward. Langkah-langkah tersebut merupakan pengembangan dari langkah-langkah model Course Review Horay menurut Huda (2013:230) dan Shoimin (2014:55).

Peningkatan pembelajaran IPS tentang jenis pekerjaan pada siswa kelas III SD Negeri 1 Wirun meliputi peningkatan proses dan hasil. Peningkatan proses diketahui berdasarkan hasil observasi penerapan model Course Review Horay dengan media 
grafis. Data hasil observasi yang dilakukan oleh 3 observer selama tiga siklus disajikan pada tabel 1. berikut:

Tabel 1. Hasil Observasi terhadap Guru dan Siswa

\begin{tabular}{lll}
\hline Siklus & Guru (\%) & Siswa (\%) \\
\hline I & 70,48 & 68,40 \\
\hline II & 85,21 & 81,52 \\
\hline III & 91,94 & 89,44 \\
\hline
\end{tabular}

Berdasarkan tabel 1., dapat diketahui bahwa penerapan model Course Review Horay dengan media grafis oleh guru dan siswa mengalami peningkatan pada tiap siklus. Persentase observasi terhadap guru pada siklus II dan III telah memenuhi indikator kinerja penelitian yang ditargetkan. Persentase observasi terhadap siswa telah memenuhi indikator kinerja penelitian pada siklus III.

Peningkatan hasil diketahui berdasarkan tes evaluasi yang diadakan setiap akhir pertemuan. Data hasil peningkatan hasil belajar IPS siklus I, II, dan III disajikan pada tabel 2. berikut:

Tabel 2. Peningkatan Hasil Belajar IPS Siswa Antarsiklus

\begin{tabular}{|c|c|c|c|}
\hline \multirow[b]{2}{*}{ Siklus } & \multicolumn{3}{|c|}{ Ketuntasan } \\
\hline & $\begin{array}{l}\text { Rata- } \\
\text { rata }\end{array}$ & $\begin{array}{l}\text { Tuntas } \\
(\%)\end{array}$ & $\begin{array}{l}\text { Belum } \\
\text { tuntas } \\
(\%)\end{array}$ \\
\hline I & 75,97 & 64,71 & 35,29 \\
\hline II & 81,69 & 79,41 & 20,59 \\
\hline III & 85,00 & 89,71 & 10,29 \\
\hline
\end{tabular}

Berdasarkan tabel 2. diketahui bahwa persentase siswa yang tuntas mengalami peningkatan pada tiap siklus. Penelitian pada siklus III telah memenuhi indikator kinerja penelitian yang ditargetkan sehingga penelitian dihentikan pada siklus III.

Peningkatan pembelajaran IPS tentang jenis pekerjaan pada siswa kelas III SD $\mathrm{N} 1$ Wirun dipengaruhi beberapa faktor yang berkaitan dengan penerapan model Course Review Horay dengan media grafis, diantaranya yaitu diskusi kelompok dan pemberian reward. Pada langkah diskusi kelompok, siswa secara berkelompok saling berlomba untuk menemukan jawaban dari soal yang diberikan oleh guru sesuai waktu yang diberikan oleh guru. Menurut Katiran (2017:23), melalui diskusi dapat membuat siswa menjadi antusias, berperan aktif, berpikir kritis, dan meningkatkan rasa ingin tahu terhadap pembelajaran IPS sehingga berpengaruh yang signifikan terhadap prestasi belajar siswa.

Pada langkah pemberian reward yang mendorong siswa untuk lebih aktif dan semangat mendapat nilai atau skor yang tinggi. Hal ini sesuai dengan pendapat Melinda dan Ratnawati (2018:83), bahwa reward atau penghargaan dapat mempermudah guru untuk meningkatkan motivasi belajar siswa dan mencapai suatu tujuan dari pembelajaran.

Namun, berdasarkan hasil wawancara dengan guru dan siswa, diketahui bahwa guru dan siswa perlu beradaptasi pada proses pembelajaran dengan menerapkan model Course Review Horay dengan media grafis karena pada pembelajaran sebelumnya belum pernah menerapkan model tersebut. Oleh karena itu wajar saja jika muncul kendala pada saat pelaksanaan pembelajaran.

Kendala yang muncul pada penerapan model Course Review Horay dengan media grafis yang dilaksanakan selama tiga siklus yaitu: (a) siswa kurang 
memperhatikan guru saat menjelaskan materi, (b) beberapa siswa kurang aktif bertanya dan berpendapat, dan (c) siswa gaduh saat meneriakkan yel-yel. Salah satu kendala tersebut sesuai dengan kelemahan dari model Course Review Horay yang diungkapkan oleh Huda (2013:231) bahwa pembelajaran dengan menerapkan model Course Review Horay dapat mengganggu suasana kelas yang lain karena siswa yang gaduh.

Adapun solusinya yaitu: (a) guru menegur dan meminta siswa untuk memperhatikan guru, dan (b) guru merangsang dan memotivasi siswa untuk percaya diri dan aktif bertanya dan berpendapat, dan (c) guru mengondisikan suasana kelas tetap kondusif. Salah satu solusi tersebut, sesuai dengan pendapat Isnayah (2016:61) bahwa guru harus selalu memotivasi siswa supaya memiliki keberanian dan kepercayaan diri untuk bertanya sehingga membangkitkan semangat belajar.

Penelitian ini relevan dengan penelitian yang dilakukan oleh Anggraeny (2017) yang menunjukkan bahwa model Course Review Horay dapat meningkatkan aktivitas dan hasil belajar siswa. Selain itu, relevan dengan hasil penelitian yang dilakukan oleh Sumarni (2017) bahwa pembelajaran dengan menggunakan media grafis dapat meningkatkan hasil belajar siswa.

\section{SIMPULAN}

Berdasarkan hasil penelitian, maka dapat disimpulkan bahwa penerapan model Course Review Horay dengan media grafis dapat meningkatkan pembelajaran IPS tentang jenis pekerjaan. Oleh karena itu, penelitian ini direkomendasikan kepada guru kelas untuk meningkatkan kualitas pembelajaran. Tindak lanjut yang dapat dilakukan yaitu mensosialisasikan model Course Review Horay dengan media grafis pada guru kelas dalam kegiatan KKG, diklat, atau kegiatan pengembangan profesionalitas guru lainnya.

\section{DAFTAR PUSTAKA}

Anggraeny. (2017). The Application Of Course Review Horay to Increase Liveliness and Learning Outcomes. Classroom Action Research Journal. Vol. 1(3), 133138.

Huda. (2013). Model-model Pengajaran dan Pembelajaran. Yogyakarta: Pustaka Belajar.

Katiran. (2017). Pengaruh Penerapan Metode Diskusi dan Penggunaan Media Pembelajaran Terhadap Prestasi Belajar Mata Pelajaran IPS Pada Siswa SDN Pudak Wetan Kecamatan Pudak Kabupaten Ponorogo. JPPI: Jurnal Penelitian dan Pendidikan IPS. Vol. 11 (1), 12-25.

Kemendikbud. (2017). Panduan Implementasi Kecakapan Abad 21 Kurikulum 2013 di Sekolah Menengah Atas. Jakarta: Dirjen Pendidikan Dasar dan Menengah.

Melinda, I. \& Ratnawati S. (2018). Pengaruh Reward dan Punishment Terhadap Motivasi Belajar Siswa. International Journal of Elementary Education. Vol. 2 (2), 81-86.

Sadiman, Arief S. (2014). Media Pendidikan Pengertian, Pengembangan, dan Pemanfaatannya. Jakarta: Rajagrafindo Persada.

Sanaky. (2015). Media Pembelajaran Interaktif-Inovatif. Yogyakarta: Kaukaba Dipantara.

Shoimin, A. (2014). 68 Model Pembelajaran Inovatif dalam Kurikulum 2013. Yogyakarta: Ar-Ruzz Media.

Sumarni. (2017). Media Grafis Kartu Pada Materi Menghargai Jasa dan Peranan Tokoh Untuk Meningkatkan Hasil Belajar IPS Siswa Kelas V. Jurnal EDUCATIO: Jurnal Pendidikan Indonesia. Vol 3 (2), 8-14. 
Volume 7 Nomor 3 Tahun 2019

Susanto, A. (2013). Teori Belajar dan Pembelajaran di Sekolah Dasar. Jakarta: Prenadamedia Group.

Tim Guru. (2018). Buku Kurikulum SD N 1 Wirun Tahun Pelajaran 2018/2019. Purworejo: SDN 1 Wirun. 